\title{
PREPARATION OF HUMAN CAPITAL FOR CHANGES: EMPIRICAL STUDY
}

\author{
Janusz Soboń ${ }^{1}$, Grzegorz Drozdowski ${ }^{2}$, Joanna Rogozińska-Mitrut ${ }^{3}$ \\ ${ }^{1,3}$ Economic Department, Jacob of Paradise University in Gorzów Wielkopolski, \\ 25 Teatralna Str., 66-400 Gorzów Wielkopolski, Poland \\ ${ }^{2}$ Department of Economics and Finance, Jan Kochanowski University in Kielce, \\ 15 Uniwersytecka Str., 25-406 Kielce, Poland \\ E-mails: ${ }^{1}$ sj@list.pl (corresponding author); ${ }^{2}$ drozdowskigp@gmail.com; ${ }^{3}$ joanna_rogozinska@wp.pl
}

Received 24 February 2020; accepted 07 May 2020

\begin{abstract}
The authors discuss a problem of analyzing the behavior of personnel participating in changes. A questionnaire, an interview and literature studies were used for the research carried out in 2019. The questionnaire was addressed to 132 employees of enterprises in the Lubusz Voivodeship of Poland. Particular attention was paid to establishing the form of involvement of the employees of the surveyed enterprises in the change process. In addition, the established self-assessment made it possible to present the participation of the surveyed staff in changes depending on the type of position held. The participation of employees in the changes was also determined in the empirical analysis due to the biographical variables included, i.e.: age, sex, seniority.
\end{abstract}

Keywords: employee, employer, human capital, organization, changes.

JEL Classification: M11, M12, M14, M21, M54.

\section{Introduction}

Implementation of tasks completed by employees often takes place in a situation characterized by uncertainty of action. Such lack of stability of functioning parameters means that the employees of the organization must treat change as a natural attribute of their work. In the literature there is a well-proven thesis that employees of contemporary companies are under pressure of constant changes. The socio-economic system has changed, the conditions for running a business have changed, and the attitude of employees towards the changes introduced in the companies in which they work is also changing. Referring to changes taking place in organizations is based on three basic paradigms. First of all, one can observe dynamic variability of the environment, which is manifested mainly in various kinds of disturbances encountered in the environment of modern companies. Secondly, there is clearly a lot of flexibility in the functioning of the organization. Organizations go through different stages of their development. As M. Juchnowicz (2012) emphasizes, the organization's flexibility has three basic dimensions: reaction time, scope and cost of the reaction. Depending on the specific conditions of the organization's operation, the strategy being implemented, emerging constraints and opportunities, these dimensions are individualized. Thirdly, the competency profiles of employees are subject to change. You can notice transformations in attitudes, behaviors, skills, personality traits, possessed values, attitudes and other attributes of employees, which in consequence determine the competitiveness of modern organizations.

In the market economy, changes are treated as a specific kind of activity of people who have made a fundamental reorganization their current philosophy of functioning (Clarke, 1997). The practice adaptations to changes are less often in crisis situations, but that engaging in changes in a turbulent environment is complex and difficult. First of all, it requires avoiding many mistakes that accompany the process of introducing changes, including what is most importantly the skillful handling of resistance among employees. Employees respond differently to changes. People's attitudes to change may depend on such factors as: the type of life attitude affecting how an individual perceives the surrounding reality, the balance of own potential profits and losses related to the introduced changes, the way in which such aspects of changes are discussed, to which the given persons can have an impact and the degree to which individuals are personally 
involved in activities related to planning and implementing changes.

Secondly, many employees do not know how to effectively deal with change. Partly, such a situation is not dependent on them and often results from the mentioned turbulences of environmental conditions. At this point, it is worth paying attention to the leadership role of the management in making changes. In such particularly radical and rapid changes, the managers should be competently prepared to engage and motivate the subordinate staff in overcoming the barriers related to the introduced changes.

A competent employee can rationally use the parameters of his knowledge by engaging in changes carried out in the enterprise. Logic and deduction can only help an employee up to a certain point, and the last episode of the process of engaging in change usually has to be overcome by overcoming emotional resistance before the change. This is because there is a high level of uncertainty and the information about this uncertainty is not reduced. Therefore, introducing changes is associated with the creation of socalled climate for change. The vision of its creation is possible when there is access to information, cooperation, and support, access to necessary capital, openness, mutual respect, courage and commitment. It is particularly important that the same information and arguments leading to the understanding and acceptance of the introduced changes are repeated several times.

Taking into account the facts presented above, it can be noticed that employees shaping their attitude towards changes introduced in organizations may approach this process differrently. The use of their competences depends on their involvement in the activities of the organization. Understanding by employees the importance of their work and role in the company improves the functioning of the organization. The proper development of the organization is favored by people accepting their own responsibility while performing tasks, recognizing their limitations, actively looking for opportunities to develop skills and free sharing of knowledge and experience. Changes in the organization cannot take place bypassing the employees employed in it. As a rule, changes affect many levels of management and introduce smaller or larger modifications in human relations. Assuming that introducing changes is a condition for the development of an organization, it would be expected that they will be accepted and supported by employees.

\section{Brief literature review}

Change is one of the basic types of human activity. Her understanding changes from whether we analyze the effects or the interior of a given organization (L. A. Berger \& D. R. Berger, 2004). Reflections on the psychosocial conditioning of organizational changes should be started with the statement that the change carried out in the organization is largely applied in 10\% of technology, and in 90\% in psychology and sociology (Schad et al., 2016).

Therefore, the employee should be treated as the basic determinant of the effectiveness of organizational changes. Hence the need to recognize and shape people's reactions to change (Cafferkey \& Dundon, 2015).

The specificity of employees' work in various case studies makes the selection of effective persuasive instruments encouraging active participation in changes is a complicated task. Adequate level of motivation to gassing in changes requires from the superiors specific skills and knowledge of the needs and expectations of employees participating in the change process. Consequently, the above theorem is consistent with the following dependence: the less significant the task of change is, the more difficult it is. Therefore, empirical considerations about change have become the basis for research carried out in organizations operating in many EU and USA (Aon, 2018; Sajdak, 2014; WłodarkiewiczKlimek, 2016; Alniacik et al., 2013; Dolot, 2017; Jang \& George, 2012; Clarke \& Clegg, 2000).

\section{Problem statement and methodology}

Employee involvement in changes should be analyzed in a way that takes into account the situational context. The willingness to be personally involved in the process of implementing changes is a key aspect that illustrates employees' attitudes towards change. The main goal of the conducted research is to show the behavior of employees in the situation of introducing changes in organizations. On this basis, an attempt was made to answer the question: in which types of behavior is the participation of employees in the changes manifested? For this purpose, it is necessary to empirically determine the types of behavior of the studied staff in the process of change. Another issue related to the research goal is to determine participation in changes depending on the biographical variables present, i.e. age, gender, 
standing and position held. Also, the level of employees' concerns about implementing changes is shown. The empirical context of the goal is an incentive to assess how employees perceive the need to participate in changes through the absorption of patterns of action that occur in both the organization and its environment.

The above assumptions provide the basis for formulating the following hypotheses regarding employee participation in changes:

$\mathrm{h}_{1}$ - Employees are characterized by behaviors similar to changes in the surveyed organizations,

$\mathrm{h}_{2}$ - behaviors of employees in the situation of changes are determined by their biographical features,

$\mathrm{h}_{3}$ - there is a different level of barriers to employees' ability to implement changes.

A questionnaire, an interview and literature studies were used for the research carried out in 2019. The questionnaire was addressed to 132 employees fulfilling their tasks in enterprises located in the Lubusz Voivodeship (or Lubuskie Voivodeship). Due to the subject of the research, the behavior of employees fulfilling executive and managerial functions in the situation of changes at the lowest management level in the organizational structure of enterprises was analyzed. The object of research is employees performing the organizational roles in the companies under study. They may be employees of the entire team (organization), or employees of one of its subunits (organizational unit). The scope of research includes the analysis of dependencies between various forms of behavior of the surveyed employees and their overcoming of barriers occurring during the implementation of changes.

\section{Results}

\subsection{Findings of the survey}

The level of employees' preparation for introducing changes in the surveyed enterprises was compared. Analysis of the percentage distribution showed that $54 \%$ of employees "support" changes introduced in their companies. The second type of behaviors in the situation of changes, or "inspiration" was represented by $30 \%$ of the surveyed people. $12 \%$ of respondents emphasized as the prevailing type of behavior "lack of commitment to change". The smallest number of employees (4\%) identified with opposition to implemented changes (Table 1).
Table 1. The behavior of the examined personnel in the situation of changes, \% (source: authors' own research)

\begin{tabular}{|l|c|c|c|c|}
\hline \multirow{2}{*}{ Employees } & \multicolumn{4}{|c|}{ Behaviors in a situation of change } \\
\cline { 2 - 5 } & I & S & L & A \\
\hline Altogether & 30 & 54 & 12 & 4 \\
\hline
\end{tabular}

Note: I - inspiring; $\mathrm{S}$ - supporting, $\mathrm{L}$ - lack of commitment, $\mathrm{A}$ - antagonism.

Analyzes carried out using a percentage distribution indicated the existence of different dominant types of employees' behavior in the situation of changes depending on the position held (Table 2).

Table 2. Behavior of the surveyed staff in the situation of changes depending on the position held, \% (source: authors' own research)

\begin{tabular}{|l|c|c|c|c|}
\hline \multirow{2}{*}{$\begin{array}{c}\text { Position } \\
\text { held }\end{array}$} & \multicolumn{4}{|c|}{ Behavior in the situation of changes } \\
\cline { 2 - 5 } & $\mathrm{I}$ & $\mathrm{S}$ & $\mathrm{L}$ & $\mathrm{A}$ \\
\hline $\begin{array}{l}\text { Managerial } \\
\text { positions }\end{array}$ & 72 & 28 & 0 & 0 \\
\hline $\begin{array}{l}\text { Executive } \\
\text { positions }\end{array}$ & 26 & 52 & 14 & 8 \\
\hline
\end{tabular}

Note: Markings as in Table 1.

The following behavior was found among the respondents representing the surveyed organizations in the situation of changes:

1. Managerial positions: dents,

a) Inspiring changes $-72 \%$ of the respondents,

b) Supporting changes $-28 \%$ of respon-

c) Lack of commitment and antagonism towards changes $-0 \%$ of the respondents,

2. Executive positions: dents,

a) Inspiration of change $-26 \%$ of respondents,

b) Supporting changes $-52 \%$ of the respon-

c) Lack of involvement in changes $-14 \%$ of the respondents,

d) Opposition to changes $-8 \%$ of the respondents.

In further searching for the types of behaviors of the surveyed employees, in the situation of introduced changes, it was revealed that the biographical features possessed determine the relationship of the surveyed people to changes. It was found that $52 \%$ of women "inspire" change. In the men surveyed, this attitude was represented 
by $38 \%$ of people. The obtained research results also showed differences in behavior towards changes due to the age of respondents. It turned out that the surveyed staff in the age group up to 50 years considered "inspiring" the most important form of participation in the changes $(64 \%)$. However, in the older age group, over 50 years old, the dominant type was "supporting change" $(36 \%)$.

The results of the research have shown that the research variable "work experience" also affects attitudes towards changes. Employees with seniority over 15 years were inclined towards the attitude of supporting change (58\%). On the other hand, employees with work experience of up to 15 years, the most important type of behavior were "inspiring" changes (Table 3).

Table 3. Behavior of the surveyed employees in the situation of changes depending on the distinguished biographical features, \% (source: authors' own research)

\begin{tabular}{|c|c|c|c|c|c|c|}
\hline \multirow{3}{*}{$\begin{array}{l}\text { Beha- } \\
\text { vior in } \\
\text { the } \\
\text { situa- } \\
\text { tion of } \\
\text { changes }\end{array}$} & \multicolumn{6}{|c|}{ Biographical features } \\
\hline & \multicolumn{2}{|c|}{ Sex } & \multicolumn{2}{|c|}{ Age [in years] } & \multicolumn{2}{|c|}{$\begin{array}{c}\text { Work } \\
\text { experience } \\
\text { [in years] }\end{array}$} \\
\hline & $\begin{array}{l}\text { Wo- } \\
\text { men }\end{array}$ & Men & $\begin{array}{c}\text { Up to } \\
50\end{array}$ & $\begin{array}{c}\text { After } \\
50\end{array}$ & $\begin{array}{c}\text { Up to } \\
15\end{array}$ & $\begin{array}{c}\text { After } \\
15\end{array}$ \\
\hline I & 52 & 38 & 64 & 32 & 60 & 30 \\
\hline $\mathrm{S}$ & 48 & 57 & 28 & 36 & 31 & 58 \\
\hline $\mathrm{L}$ & 0 & 5 & 8 & 20 & 9 & 8 \\
\hline $\mathrm{A}$ & 0 & 0 & 0 & 12 & 0 & 4 \\
\hline
\end{tabular}

Note: Markings as in Table 1.

Table 4. Distribution of the level of intensity of experienced fears occurring among the surveyed employees during the implementation of changes $(\mathrm{n}=132)$ (source: authors' own research)

\begin{tabular}{|l|c|c|c|c|c|c|}
\hline $\begin{array}{c}\text { Type of felt } \\
\text { concern }\end{array}$ & FC & OE & FD & FL & OM & LS \\
\hline $\begin{array}{l}\text { The number of } \\
\text { people studied } \\
\text { experiencing the } \\
\text { fears }\end{array}$ & 16 & 19 & 38 & $\mathbf{4 6}$ & 8 & 5 \\
\hline
\end{tabular}

Note: FC - fear of introducing changes, OE Objection of revealing errors, FD - fear of deterioration of the company, FL - fear of lack of success, OM - fear of maintaining outdated management methods, LS - fear of lack of support from superiors (managers).
Statistical analysis of the third hypothesis showed a different attitude of the surveyed personnel to changes from the point of view of perceived fears (Table 4). It turned out that employees are most afraid of the lack of expected successes after implementing the planned changes (46 people). Equally high, the respondents placed a barrier related to the fear of deterioration in the functioning of the organization in which they work. The least concern was related to the lack of support from the management in a situation of change.

\subsection{Interpretation of the findings}

Generally, it can be stated that the structure of employees' behavior in a situation of change oscillated between two extreme types of behavior, i.e. inspiring changes, or antagonism towards their introduction. In this light of empirical interpretation, two categories of behavior clearly dominate: supporting changes and inspiring them (Figure 1). The remaining types of behaviors were marked in the trace form, in particular antagonistic behaviors in favor of introducing changes. These types of behaviors, which are taken into account when interpreting the involvement of the personnel under study in the change process, make it possible to present conclusions that employees will see the inevitable need for changes and their support is a condition for the dynamism of the process being analyzed.

\section{Percentage}

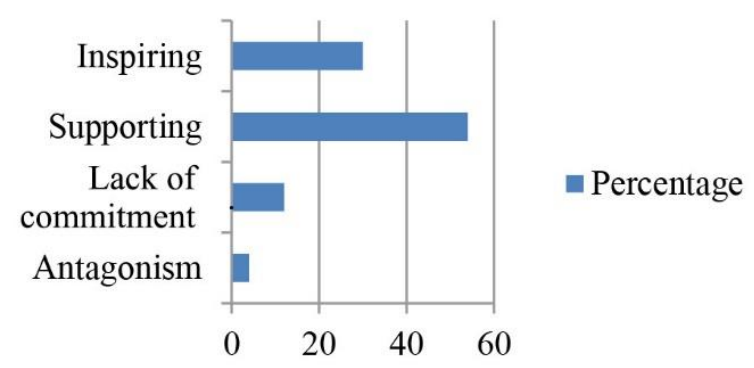

Figure 1. Involvement of the examined personnel in the situation of changes, $\%$ (source: authors' own research)

Interpreting the results of the research, it can be also noticed that during the implementation of the changes, not all kinds of fears get a high level in the same number of employees. The dominant fear is the fear of lack of success visible after the change. Employees usually want to get to know the results of their work as soon as possible. By undertaking an additional effort to solve problems during the implementation of changes, the staff 
expects the first achievements to appear after a short time. Too long introduction of new qualitative changes often leads to weakening of motivation, weariness and often even discouragement.

The results of the conducted empirical verification confirmed that the level occupied in the organizational structure by the surveyed personnel determines the type of involvement in the change process. In management positions, the dominant behavior was to inspire change. However, at the executive positions, the primary type of commitment was to support change. As shown by the results of the surveyed employee sample, the antagonism towards changes was characterized slightly, by the behavior of persons occupying executive positions. A characteristic feature of respondents' answers worth emphasizing is a slight indication of their lack of commitment to change. This may indicate that the staff is aware of the fact that today's change should be treated as a completely natural thing.

The empirical meaning of research into the dependencies of the employee participation categories considered in the change process from biographical variables led to the verification of the $\mathrm{h}_{2}$ hypothesis. The interrelations between the distinguished types of behavior in the situation of changes and the biographical features characterizing the surveyed personnel were interpreted in the course of the analysis.

It is worth noting that the following conclusions were made for staff involved in the change process:

1. The age of the surveyed staff determined the identified categories of involvement in the change process.

2. The form of behavior during the changes was differentiated due to the sex of the examined persons.

3. Work experience determined selected categories of involvement in the change process.

4. Among the surveyed employees there is often a high level of fear of lack of success visible in the foreseeable time perspective and fear of deterioration of the organization's functioning.

The least likely is the fear of continuing to maintain outdated management methods, as well as the lack of commitment on the part of superiors.

\section{Conclusion and discussion}

Correct implementation of changes depends on the conduct and behavior of people in a given organization. Favorable factors that facilitate their implementation may include an employee's understanding of the importance of his contribution and role in the company, recognizing limitations in his own operation, and accepting responsibility in solving problems. High involvement of employees, sharing their knowledge and experience in a significant way contributes to the successful implementation of changes.

During the implementation of changes, however, barriers appear that arise from employees' fears of losing stability, revealing their mistakes or deteriorating the company's operations. Many people are afraid that their possible successes may appear only after a longer period. There are also fears that the recognition of the superiors will concern the achievements of the whole team, not individual employees. Employees often suspect that despite the submission of certain declarations, management's reluctance to delegate rights or maintaining old management methods will continue to occur. They are also concerned about the lack of management's involvement in the process of implementing the system. Understanding, recognizing and counteracting existing concerns may contribute to improving the effectiveness of change implementttation as well as organization of work in the enterprise.

The obligation of the employed staff in addition to performing tasks related to the current goals is to perform functions that condition their preparation for the implementation of changes. In a state of poor competence preparation, it can be much more difficult, less effective or even impossible. Therefore, taking steps to provide the best insight into the degree of employee preparation for change is an important task that determines the effective conduct of this process in enterprises. It is unlikely that employees not prepared to participate in this situation can effectively engage in the change process.

The conducted research was focused around subjective correlates of the participation of the surveyed staff in the changes. Research results indicate that employees declare support for change as their form of participation in this process. This information is important for management and other parties concerned interested in achieving success. It indicates the need to undertake preparatory activities in relation to the 
personnel involved in the changes. The presented research has shown preparation for changes in the form of creative behavior (inspiration) in managerial positions in the surveyed organizations. It can bring positive results not only in terms of achieving goals, but also in terms of personal effects, as to the fulfillment of its role as a "transformational leader".

The results of the study showed that women are an advantage over men as inspiring people for change. This means that women in difficult (variable) situations can become leaders in the process of implementing changes. Important information regarding the relations between the surveyed biographical variables of employees and their preparation for change is the statement that age (up to 50 years) favors inspirational attitudes towards change. This state of affairs suggests mastering the ability to manage change, which means that there is a certain optimal level of development of this attitude, limiting the intensification of defensive behavior.

The research undertaken indicates the relationship between the behavior of the staff in the situation of change and a separate biographical feature of the seniority. The surveyed employees with seniority over fifteen years used the preparation for change in their assessment, more often with supportive rather than inspiring attitudes. This dependence can be clearly stated, despite less willingness to inspire changes among employees over 50 years of age. This may mean that the degree of involvement increases with the experience at work.

The research presented indicates that there is a different level of concern for employees. The prevailing fear among employees is the fear of the lack of success after the implementation of changes in the organization. The staff is much more motivated to act if it is convinced that the achieved effects of engagement in changes are real. It can be concluded that the completion of specific changes should occur before losing motivation on the part of the staff concerned. Employees' usual fears of introduced changes (especially badly prepared) are associated with the loss of financial security and intangibles. They are afraid of losing stability and increasing the occurrence of unpredictable disruptions in their work.

Every employee joining the changes has initial settings. The scale of perceived by employees in the implementation of changes differs depending on the level of motivation of people involved in this process. As the level of employee motivation increases, the level of fear of change decreases. The role of the management team is to reduce first of all the intensity of fears of lack of success and deterioration of the functioning of the organization. In addition, supervisors should remember to create a friendly climate for change by eliminating barriers related to fear of making mistakes. Further, as shown by the studies presented, the task of managers should be to ensure the introduction of new quality management methods and to actively support subordinate personnel in a situation of change.

\section{References}

Alniacik, E., Alniacik, Ü., Erat, S., \& Akçin, K. (2013). Does person-organization fit moderate the effects of affective commitment and job satisfaction on turnover intentions? Procedia Social and Behavioral Sciences, 99, 274-281. https://doi.org/10.1016/j.sbspro.2013.10.495

Aon. (2018). Global trends in employee engagement. www.aon.com/poland/hr/raporty

Berger, L. A., \& Berger, D. R. (2004). The talent management handbook: creating organizational excellence by identifying, developing and promoting your best people. The McGraw-Hill Companies.

Bratnicki, M. (2018). W poszukiwaniu ram teoretycznych dla zarządzania zmianą strategiczną. Wyzwania dla konwencjonalnej mądrości [In search of the theoretical framework for strategic change management. Challenges for conventional wisdom]. In Innowacyjna gospodarka, innowacyjne organizacje, innowacyjni ludzie. Prace Naukowe, UE w Katowicach, Katowice. (in Polish).

Cafferkey, K., \& Dundon, T. (2015). Explaining the black box: HPWS and organisational climate. Personnel Review, 44(5), 666-688. https://doi.org/10.1108/PR-12-2012-0209

Clarke, L. (1997). Zarządzanie zmiana [Change management]. Wyd. Gebethner i Ska (in Polish).

Clarke, T., \& Clegg, S. (2000). Management paradigm for the new millennium. International Journal for Management Reviews, 2(1), 45-64. https://doi.org/10.1111/1468-2370.00030

Dolot, A. (2017). The observed and expected behavior of immediate superiors: The employees' perspective. In A. Postuła \& M. Darecki (Eds.), Przedsiębiorczość $w$ teorii $i$ badaniach. Perspektywa młodych badaczy. Wydawnictwo Naukowe Wydziału Zarządzania Uniwersytetu Warszawskiego.

Filipowicz, G. (2014). Zarzadzanie kompetencjami. Perspektywa firmowa $i$ osobista [Competence management. Corporate and personal perspective]. Wyd. Wolters Kluwer (in Polish). 
Jang, J., \& George, R. T. (2012). Understanding the influence of polychronicity on job satisfaction and turnover intention: A study of nonsupervisory hotel employees. International Journal of Hospitality Management, 31(2), 588595. https://doi.org/10.1016/j.ijhm.2011.08.004

Juchnowicz, M. (2012). Zaangażowanie pracowników. Sposoby oceny $i$ motywowania [Involvement of employees. Ways of assessment and motivation]. PWE, Warszawa (in Polish).

Sajdak, M. (2014). Zwinność w odpowiedzi współczesnych przedsiębiorstw na nowe wyzwania otoczenia. Studia Oeconomica Posnaniensia, 2(11).

Schad, J., Lewis, M. W., Raisch, S., \& Smith, W. K. (2016). Paradox research in management science. Looking back to move forward. The Academy of Management Annals, 10(1). https://doi.org/10.1080/19416520.2016.1162422

Włodarkiewicz-Klimek, H. (2016). Koncepcja i modele zwinnego przedsiębiorstwa. Zeszyty Naukowe Politechniki Poznańskiej, (71), 213225.

https://doi.org/10.21008/j.0239-9415.2016.071.19 